\title{
What Is Wrong with Pertussis Vaccine Immunity?
}

\section{The Problem of Waning Effectiveness of Pertussis Vaccines}

\author{
Nicolas Burdin, ${ }^{1}$ Lori Kestenbaum Handy, ${ }^{2}$ and Stanley A. Plotkin ${ }^{3}$ \\ ${ }^{1}$ EU Research and Non Clinical Safety, R\&D, Sanofi Pasteur, Campus Mérieux, 69280 Marcy l'Etoile, France \\ ${ }^{2}$ Assistant Professor of Pediatrics, Sidney Kimmel Medical College at Thomas Jefferson University, Division \\ of Infectious Diseases, Nemours/Alfred I. duPont Hospital for Children, Wilmington, Delaware 19803 \\ ${ }^{3}$ Emeritus Professor of Pediatrics, University of Pennsylvania, Vaxconsult, Doylestown, Pennsylvania 18902 \\ Correspondence: stanley.plotkin@vaxconsult.com
}

Pertussis is resurgent in some countries, particularly those in which children receive acellular pertussis (aP) vaccines in early infancy and boosters later in life. Immunologic studies show that, whereas whole-cell pertussis (WP) vaccines orient the immune system toward Th1/Th17 responses, acellular pertussis vaccines orient toward Th1/Th2 responses. Although aP vaccines do provide protection during the first years of life, the change in T-cell priming results in waning effectiveness of aP as early as $2-3$ years post-boosters. Although other factors, such as increased virulence of pertussis strains, better diagnosis, and better surveillance may play a role, the increase in pertussis appears to be the result of waning immunity. In addition, studies in baboon models, requiring confirmation in humans, show that aP is less able to prevent nasopharyngeal colonization of Bordetella pertussis than wP or natural infection.

\section{GREAT DEBATES}

What are the most interesting topics likely to come up over dinner or drinks with your colleagues? Or, more importantly, what are the topics that don't come up because they are a little too controversial? In Immune Memory and Vaccines: Great Debates, Editors Rafi Ahmed and Shane Crotty have put together a collection of articles on such questions, written by thought leaders in these fields, with the freedom to talk about the issues as they see fit. This short, innovative format aims to bring a fresh perspective by encouraging authors to be opinionated, focus on what is most interesting and current, and avoid restating introductory material covered in many other reviews.

The Editors posed 13 interesting questions critical for our understanding of vaccines and immune memory to a broad group of experts in the field. In each case, several different perspectives are provided. Note that while each author knew that there were additional scientists addressing the same question, they did not know who these authors were, which ensured the independence of the opinions and perspectives expressed in each article. Our hope is that readers enjoy these articles and that they trigger many more conversations on these important topics.

Editors: Shane Crotty and Rafi Ahmed

Additional Perspectives on Immune Memory and Vaccines: Great Debates available at www.cshperspectives.org

Copyright (C) 2017 Cold Spring Harbor Laboratory Press; all rights reserved; doi: 10.1101/cshperspect.a029454 Cite this article as Cold Spring Harb Perspect Biol 2017;9:a029454 
N. Burdin et al.

Psant ertussis is a respiratory disease caused by several species of Bordetella, particularly $B$. pertussis. Inactivated and alum-adjuvanted whole-cell vaccines against pertussis were developed early in the 20th century and shown to have reasonable efficacy, at least in children. However, the specifics of whole-cell vaccines differed from manufacturer to manufacturer, resulting in variable reactogenicity and efficacy. A pooled estimate of efficacy of whole-cell vaccines gave an estimate of $78 \%$ with a wide range, but was flawed by differences in exposure (Jefferson et al. 2003).

Dissatisfaction with reactions to $\mathrm{wP}$ vaccines, real or perceived, led to their replacement by aP vaccines at the end of the 20th century. In the 1990s, many safety and efficacy studies of the new vaccines were conducted, but interpretation of the results was clouded by three problems: the differences between the whole-cell vaccines used as comparators, the varying concentrations of antigens contained in the candidate acellular vaccines, and the absence, for the most part, of head-to-head comparisons among the many acellular vaccines tested. Expert opinions about the results were not uniform but all observers concluded that aP vaccines are less reactogenic and that no aP vaccine was clearly superior in efficacy to a good whole-cell vaccine, whereas some asserted that multiple pertussis antigen acellular vaccines were superior in efficacy to those containing one or two antigens (Greco 1996; Gustafsson 1996; Olin 1997).

Acellular pertussis vaccines were adopted by the United States and many European countries later in the 1990s. Japan had adopted acellular vaccines even earlier in the 1980s. In subsequent years, the better tolerability of acellular vaccines was confirmed so, in that respect, the new vaccines were successful, but then the incidence of pertussis seemed to increase in the face of vaccination both in vaccinated and unvaccinated school children and adolescents. Although other possible explanations were proposed (Kilgore et al. 2016; Sealey et al. 2016), the resurgence of pertussis infections in several countries with high vaccination coverage raised questions about the nature and durability of vaccine-induced immunity (Domenech de Celles et al.
2016; Locht 2016). As reviewed below, epidemiological studies showed that the new vaccines were indeed protective in the first years after vaccination (Bisgard et al. 2005) but that protection was temporary, with rapid waning as years passed postvaccination (Plotkin et al. 2014a,b). While duration of immunity after wP has not been directly compared to that after aP, old studies suggest longer effectiveness of the former (Wendelboe et al. 2005). To complicate matters, studies in the baboon model of pertussis (also described below) suggested that acellular vaccines do not prevent colonization by the pertussis organism or its transmission to other animals. Both of these phenomena decrease the value of acellular vaccines and require immunologic explanations to improve the vaccines now in use. It should be added that a return to wholecell vaccines will not be acceptable to the countries now using aP and other solutions must be found.

\section{IMMUNE PROTECTION BY NATURAL INFECTIONS}

Immunity to $B$. pertussis has not been extensively studied over the past decades. Some recent studies are shedding light however on the innate and adaptive immune arms involved in pertussis infections (Brummelman et al. 2015b; Higgs et al. 2012). The actual duration of protection conferred by natural infection in humans is not fully established, but is thought to range between 10 and 20 years. Duration of protection varies among individuals but also among studies, partly because of varying rates of asymptomatic exposures to the natural pathogen (Domenech de Celles et al. 2016; Wendelboe et al. 2005). While no studies have been designed to specifically address this question, laboratoryconfirmed cases of reinfection have clearly been documented, suggesting that natural infections do not completely protect people from being reinfected $10-15$ years post-primary infection (Wirsing von Konig et al. 1995; Versteegh et al. 2002). The number of well-documented cases of recurrent disease is limited, indicating that natural immunity is nonetheless rather robust. Vaccines that can achieve similar 
immunity to that induced by natural infections should be more than satisfactory and better than what current primary and booster pertussis vaccines can provide for long-term protection (Cherry 2014).

\section{VACCINES: FROM WHOLE-CELL TO SUBUNIT VACCINES}

The introduction of $\mathrm{wP}$ vaccines in the $1940 \mathrm{~s}$ with gradual extension to most countries drastically reduced the occurrence of whooping cough by $99 \%$. Because of significant side effects such as low grade fewer, local reactions, and some more severe rare adverse events subunit acellular vaccines based on one to five Bordetella antigens (Ags) (pertussis toxin $[\mathrm{PT}]$, pertactin [PRN], filamentous hemagglutinin [FHA] fimbriae 2 and 3) were developed in the early 1990s, first used as toddler and school-entry boosters and then several years later introduced as well for primary infant vaccination (Decker et al. 1995; Edwards et al. 1995; Pichichero et al. 1997; Sheridan et al. 2014; World Health Organization 2015). Whole-cell pertussis vaccines varied in quality, but the best ${ }_{\mathrm{wP}} \mathrm{P}$ vaccines gave very good protection (Plotkin 1997; Plotkin and Cadoz 1997), and the antibody levels they induced were efficiently boosted by aP vaccines (Pichichero et al. 2005, 2006). After wP priming, memory $B$ cells persist longer than circulating antibody (Hendrikx et al. 2011b). In contrast, pertussis-specific T-cell responses do not persist nearly as well after aP priming (Palazzo et al. 2016).

\section{THE DURATION OF EFFECTIVENESS PROBLEM: WANING IMMUNITY}

The conversion from wP to aP solved the reactogenicity problem, but contributed to another: faster waning of immunity in adolescents given aP booster vaccines after aP priming, contributing to the resurgence of pertussis and to the perception that aP vaccines are insufficiently effective. Resurgence of pertussis, predicted by Hewlett and Edwards (2005), may not be due entirely to waning immunity. There have been genetic changes in B. pertussis (Cherry 2012), improved diagnostics and differing case definitions, additional public health surveillance, and collections of unvaccinated populations, although these factors will not be discussed in detail here. Among the many proposed factors leading to resurgence, the striking decline in effectiveness over time after "distant" booster vaccination forces us to focus on immunologic memory.

Initial efficacy studies for both $\mathrm{wP}$ and $\mathrm{aP}$ were conducted over short periods of time and showed that $\mathrm{aP}$ vaccines were indeed protective. Investigators in Europe and Senegal worked to determine estimates of long-term efficacy. These studies of children who received a threeor four-dose series suggested that protection waned faster after aP than after wP (Salmaso et al. 2001; Lugauer et al. 2002; Lacombe et al. 2004).

After both a three-dose and five-dose primary series of aP, protection predictably wanes after the last dose of the series, with the odds of pertussis increasing by 1.33 times (95\% CI $1.23-$ 1.43) for every year after receipt of diphtheria, tetanus, and acellular pertussis $(\mathrm{DTaP})^{4}$ (McGirr and Fisman 2015). Epidemiological studies confirm that protection, whereas robust at time of vaccination, is temporary with waning immunity as years pass postvaccination (Table 1 , Fig. 1). Waning immunity after aP was suggested early after its introduction (Lugauer et al. 2002; Lacombe et al. 2004). It became evident in the 2010 California epidemic, in which infants who could not be vaccinated because of young age were at highest risk of infection. Also striking was that $66 \%$ of cases in fully vaccinated children were in the 7- to 10-year-old age group, who had previously received only aP, suggestive of waning immunity (Winter et al. 2012). In Spain, where aP was not adopted until 2005, the incidence rate of disease significantly increased in 2010-2012 in all age groups, including unvaccinated infants $<3$ mo of age (Sizaire et al. 2014). Taken together, those epidemiology studies indicate that an aP primary series — when compared to a wP pri-

${ }^{4}$ Diphtheria, tetanus, and acellular pertussis vaccine used for infants and young children, often combined with other routine childhood vaccines. 
N. Burdin et al.

Table 1. Studies demonstrating waning effectiveness

\begin{tabular}{|c|c|c|c|c|c|}
\hline $\begin{array}{l}\text { Year location/ } \\
\text { reference }\end{array}$ & Study design & $\begin{array}{c}\text { Patient } \\
\text { population }\end{array}$ & Vaccine & Statistical measure & Results \\
\hline $\begin{array}{l}\text { 2002-2010, } \\
\text { Minnesota, } \\
\text { United States } \\
\text { (Tartof et al. } \\
\text { 2013) }\end{array}$ & Cohort & $\begin{array}{l}\text { 224,378 children: } \\
458 \text { cases }\end{array}$ & $\begin{array}{c}\text { Five doses } \\
\text { DTaP }\end{array}$ & $\begin{array}{l}\text { Risk ratio } \\
\text { reference: year } 1 \\
\text { after vaccination } \\
\text { series }\end{array}$ & $\begin{array}{l}\text { Year after fifth dose: } \\
\text { RR (95\% CI) } \\
\text { 2: } 1.9(1.3-2.9) \\
\text { 3: } 2.6(1.7-3.8) \\
\text { 4: } 3.2(2.1-4.8) \\
\text { 5: } 6.1(4.1-8.9) \\
6: 8.9(6.0-13.0)\end{array}$ \\
\hline $\begin{array}{l}\text { 2002-2010, } \\
\quad \text { Oregon, } \\
\text { United States } \\
\text { (Tartof et al. } \\
\text { 2013) }\end{array}$ & Cohort & $\begin{array}{l}\text { 179,011 children: } \\
89 \text { cases }\end{array}$ & $\begin{array}{c}\text { Five doses } \\
\text { DTaP }\end{array}$ & $\begin{array}{l}\text { Risk ratio } \\
\text { reference: year } 1 \\
\text { after vaccination } \\
\text { series }\end{array}$ & $\begin{array}{l}\text { Year after fifth dose: } \\
\text { RR (95\% CI) } \\
\text { 2: } 1.3(0.6-2.8) \\
\text { 3: } 1.5(0.7-3.7) \\
\text { 4: } 1.7(0.8-3.7) \\
\text { 5: } 2.6(1.2-5.6) \\
\text { 6: } 4.0(1.9-8.4)\end{array}$ \\
\hline $\begin{array}{l}\text { 2005-2009, } \\
\text { Australia } \\
\text { (Quinn et al. } \\
\text { 2014) }\end{array}$ & $\begin{array}{l}\text { Matched } \\
\text { case- } \\
\text { control }\end{array}$ & $\begin{array}{l}3123 \text { cases, } \\
61,636 \\
\text { controls }\end{array}$ & $\begin{array}{l}\text { Three } \\
\text { doses } \\
\text { DTaP }\end{array}$ & $\begin{array}{l}(1-\mathrm{OR}) \times 100 \\
\text { reference: } \\
\text { unvaccinated } \\
\text { patients }\end{array}$ & $\begin{array}{l}\text { Age in years: } \\
\text { VE\% }(95 \% \mathrm{CI}) \\
\text { 1: } 79.2(75.0-82.8) \\
\text { 2: } 70.7(64.5-75.8) \\
\text { 3: } 59.2(51.0-66.0)\end{array}$ \\
\hline $\begin{array}{l}\text { 2006-2011, } \\
\text { California, } \\
\text { United States } \\
\text { (Klein et al. } \\
\text { 2012) }\end{array}$ & Case-control & $\begin{array}{l}277 \text { cases, } \\
\text { matched } \\
\text { controls }\end{array}$ & $\begin{array}{r}\text { Five doses } \\
\text { of DTaP }\end{array}$ & $\begin{array}{l}\text { Odds ratio } \\
\text { reference: PCR- } \\
\text { negative } \\
\text { controls }\end{array}$ & $\begin{array}{l}\text { Odds ratio } \\
\text { (95\% CI) per year after } \\
\text { fifth DTaP dose, } 1.42 \\
(1.21-1.66)\end{array}$ \\
\hline $\begin{array}{l}\text { 2006-2015, } \\
\text { California, } \\
\text { United States } \\
\text { (Klein et al. } \\
\text { 2016) }\end{array}$ & Cohort & $\begin{array}{l}\text { 279,493 children: } \\
1207 \text { cases }\end{array}$ & $\begin{array}{l}\text { DTaP } \\
\text { primary } \\
\text { series } \\
+1 \\
\text { Tdap }\end{array}$ & $\begin{array}{l}(1-\mathrm{HR}) \times 100 \\
\text { reference: Tdap- } \\
\text { unvaccinated } \\
\text { patients }\end{array}$ & $\begin{array}{l}\text { Years post-Tdap: } \\
\text { VE\% }(95 \% \mathrm{CI}) \\
\leq 1: 68.8(59.7-75.9) 2 \text { : } \\
\text { 56.9 (41.3-68.4) } \\
\text { 3: } 25.2(-4.3-46.4) 4+: \\
\text { 8.9 }(-30.6-36.4)\end{array}$ \\
\hline $\begin{array}{l}\text { 2010, Marin } \\
\text { County, CA, } \\
\text { United States } \\
\text { (Witt et al. } \\
\text { 2012) }\end{array}$ & $\begin{array}{l}\text { Population- } \\
\text { based } \\
\text { cohort }\end{array}$ & $\begin{array}{l}\text { 22,798 children: } \\
132 \text { cases }\end{array}$ & $\mathrm{aP}$ & $\begin{array}{l}\text { Screening method } \\
\text { 1-[PCV } / \\
\quad(1-\mathrm{PCV})] \times \\
{[(1-\mathrm{PPV}) / \mathrm{PPV}]}\end{array}$ & $\begin{array}{l}\text { Age in years: } \\
\qquad \begin{array}{l}\text { VE\% }(95 \% \mathrm{CI}) \\
\text { 2-7: } 41(21-54) \\
8-12: 24(0-40) \\
13-18: 79(73-84)\end{array}\end{array}$ \\
\hline $\begin{array}{l}\text { 2010, California, } \\
\text { United States } \\
\text { (Misegades } \\
\text { et al. 2012) }\end{array}$ & Case-control & $\begin{array}{l}682 \text { cases, } \\
2016 \text { controls }\end{array}$ & $\begin{array}{c}\text { Five doses } \\
\text { DTaP }\end{array}$ & $\begin{array}{l}(1-\mathrm{OR}) \times 100 \\
\text { reference: } \\
\text { unvaccinated } \\
\text { patients }\end{array}$ & $\begin{array}{l}\text { Months since fifth dose: } \\
\text { VE\% (95\% CI) } \\
\quad<12: 98.1(96.1-99.1) \\
\text { 12-23: } 95.3(91.2-97.5) \\
\text { 24-35: } 92.3(86.6-95.5) \\
\text { 36-47: } 87.3(76.2-93.2) \\
\text { 48-59: } 82.8(68.7-90.6) \\
\text { 60-83: } 71.2(45.8-84.8)\end{array}$ \\
\hline $\begin{array}{l}2012, \\
\text { Washington, } \\
\text { United States } \\
\text { (Acosta et al. } \\
\text { 2015) }\end{array}$ & Case-control & $\begin{array}{l}\text { Adolescents: } \\
450 \text { cases, } \\
1246 \text { controls }\end{array}$ & Tdap & $\begin{array}{l}(1-\mathrm{OR}) \times 100 \\
\text { reference: Tdap- } \\
\text { unvaccinated } \\
\text { patients }\end{array}$ & $\begin{array}{l}\text { Months postvaccination: } \\
\text { VE\% }(95 \% \mathrm{CI}) \\
\quad<12: 73.1(60.3-81.8) \\
\text { 12-23: } 54.9(32.4-70.0) \\
\text { 24-47: } 34.2 \\
\text { (-0.03-58.0\%) } \\
\text { Overall: } 63.9(50-74)\end{array}$ \\
\hline
\end{tabular}

Continued 
Waning Effectiveness of Pertussis Vaccines

Table 1. Continued

\begin{tabular}{|c|c|c|c|c|c|}
\hline $\begin{array}{l}\text { Year location/ } \\
\text { reference }\end{array}$ & Study design & $\begin{array}{c}\text { Patient } \\
\text { population }\end{array}$ & Vaccine & Statistical measure & Results \\
\hline $\begin{array}{l}\text { 2012, Wisconsin, } \\
\text { United States } \\
\text { (Koepke et al. } \\
\text { 2014) }\end{array}$ & Cohort & $\begin{array}{l}\text { Adolescents: } \\
940 \text { cases } \\
\text { matched to } \\
\text { Tdap- } \\
\text { vaccinated } \\
\text { controls }\end{array}$ & Tdap & $\begin{array}{l}(1-\mathrm{IRR}) \times 100 \\
\text { reference: Tdap- } \\
\text { unvaccinated } \\
\text { patients }\end{array}$ & $\begin{array}{l}\text { Year postvaccination: VE\% } \\
\text { (95\% CI), baseline: } \\
\quad<1: 75.3(55.2-86.5) \\
\text { 1: } 68.2(60.9-74.1) \\
\text { 2: } 34.5(19.9-46.4) \\
\text { 3-4: } 11.9(-11.1-30.1)\end{array}$ \\
\hline $\begin{array}{l}\text { 2012, Oregon, } \\
\text { United States } \\
\text { (Liko et al. } \\
\text { 2014) }\end{array}$ & $\begin{array}{l}\text { Population- } \\
\text { based } \\
\text { cohort }\end{array}$ & $\begin{array}{l}709 \text { cases ages } \\
2 \text { mo-19 years } \\
\text { partially or } \\
\text { fully } \\
\text { vaccinated }\end{array}$ & $\mathrm{aP}$ & $\begin{array}{l}\text { [1-(AR } \\
\quad \text { vaccinated/AR } \\
\quad \text { unvaccinated })] \\
\quad \times 100\end{array}$ & $\begin{array}{l}\text { Age: } \mathrm{VE} \%(95 \% \mathrm{CI}) \\
\text { 15-47 mo old: } \\
95 \text { (92-97) } \\
4-6 \text { yo: } 89(81-94) \\
7-10 \text { yo: } 83(72-90) \\
11-12 \text { yo: } 65(46-78) \\
13-16 \text { yo: } 47(19-65) \\
17-19 \text { yo: } 66(30-84)\end{array}$ \\
\hline
\end{tabular}

AR, Attack rate; HR, hazard ratio; IRR, incidence rate ratio; OR, odds ratio; PCR: polymerase chain reaction, PCV, proportion of cases vaccinated; PPV, proportion of population vaccinated; RR, relative risk.

mary series_elicits an insufficient priming to ensure optimal boosting and long-term protection, especially in response to the later aP boosters in adolescents.

\section{ACELLULAR VACCINES: HOW DO THEY PROTECT COMPARED TO KILLED wP VACCINES?}

Thus, clinical and epidemiology results showed that protection induced by aP vaccines was potent and quite similar or better than the one achieved with wP (Edwards and Decker 2013). The improved safety profile led to the decision to switch to aP vaccines alone in most developed countries initiated in the mid-1990s (Klein 2014). A review of effectiveness and efficacy studies of wP and currently available aP vaccines suggested that even after the primary series, aP vaccines are less efficacious (84\%) than wP vaccines are effective (94\%) (Fulton et al. 2016). However, the heterogeneity of whole-cell vaccines and the paucity of clinical trials using them make conclusions difficult.

Studies in Australia and the United States suggested that patients primed with wP have longer-lasting protection than those who had aP, although because of variability in ${ }^{\mathrm{P}}$ it is unknown whether that is also the case in countries with a less efficacious wP vaccine (Sheridan et al. 2012, 2014; Klein et al. 2013; Liko et al. 2013; Witt et al. 2013). Even with a five-dose DTaP series and Tdap ${ }^{5}$ booster, adolescents immunized in infancy with DTaP instead of at least the first dose of the primary series having been wP vaccine had an increased incidence of pertussis disease (Liko et al. 2013; Skoff and Martin 2016).

The main differences identified in humans between immune responses induced by aP vaccines compared to those triggered by wP or natural infections are detailed in Table 2. Those results remain still rather limited for vaccines having been licensed for decades and can even be sometimes a bit contradictory. Some overall trends nonetheless emerge but should be analyzed with caution and require further investigation.

\section{IMMUNE RESPONSES TO PERTUSSIS VACCINES IN HUMANS}

Even if no correlates of protection have been widely accepted for pertussis vaccines, it is

\footnotetext{
${ }^{5}$ Tetanus, reduced diphtheria, and acellular pertussis vaccine used for older children/adolescents and adults, sometimes combined with inactivated poliovirus vaccine.
} 
N. Burdin et al.
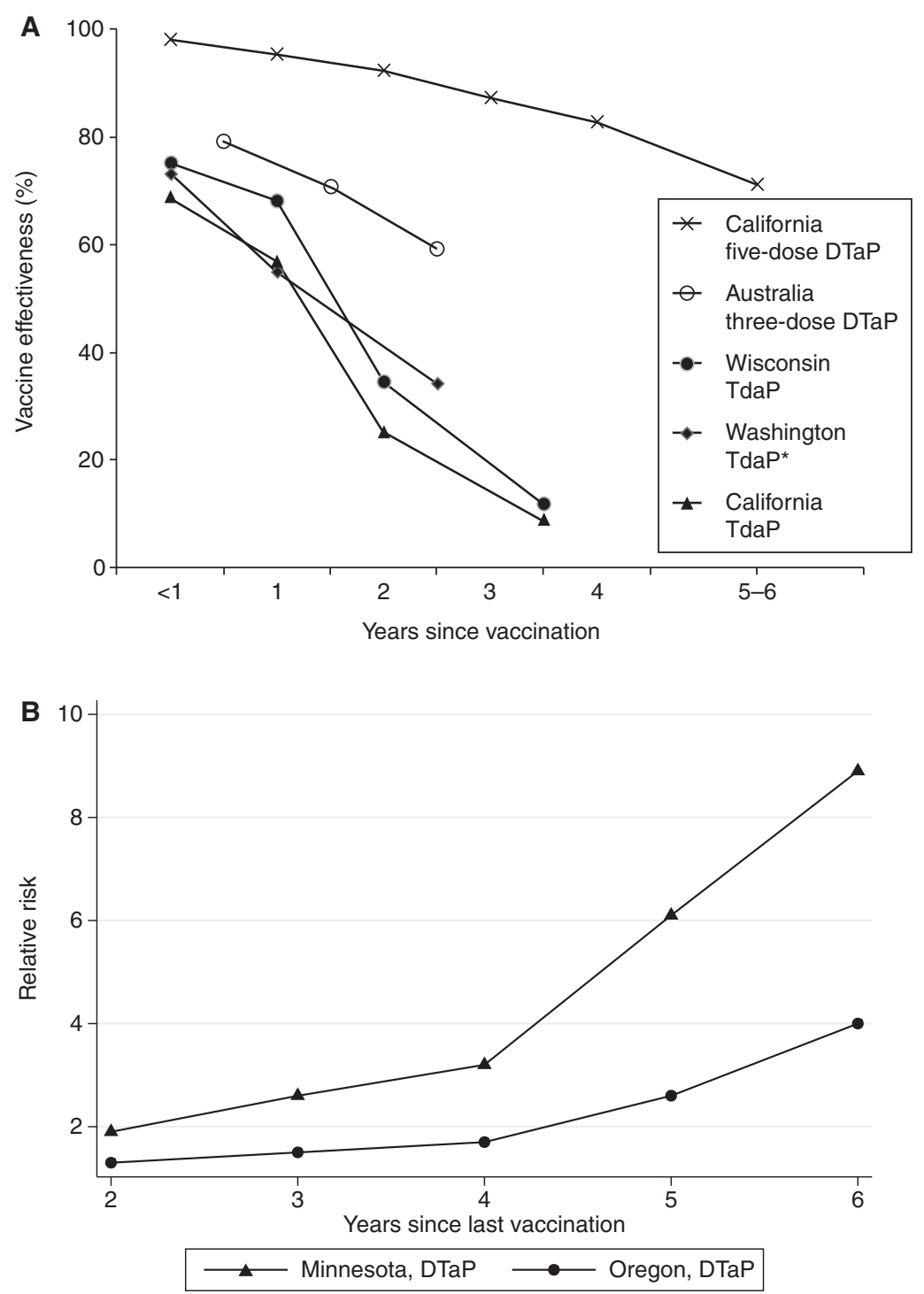

Figure 1. (A) Demonstration of waning immunity following either infant/early childhood diphtheria, tetanus, and acellular pertussis (DTaP) or early adolescent tetanus, reduced diphtheria, and acellular pertussis (TdaP), measured as vaccine effectiveness. Vaccine effectiveness was calculated in each study as described in Table 1 . The California five-dose study refers to Misegades et al. (2012), whereas the TdaP study refers to Klein et al. (2016). * Last point is $24-47$ mo post-booster. $(B)$ Demonstration of waning immunity with DTaP measured as relative risk (RR) of infection, with regard to first-year post-booster vaccination.

well documented that $\mathrm{Ab}$ responses are critical effectors to mediate protection. PT antibodies are particularly correlated with protection (Plotkin 2013). On a wP priming background, aP boosters induce circulating $\mathrm{Ab}$ levels that rapidly increase and decrease within months, but remain well above pre-booster baselines for years (Baretto et al. 2007; Dalby et al. 2010), and are well recalled on additional boosting (Pichichero et al. 2005, 2006; Baretto et al. 2007; Halperin et al. 2012). Antibody and B-cell responses elicited by aP vaccines seem to be 
Waning Effectiveness of Pertussis Vaccines
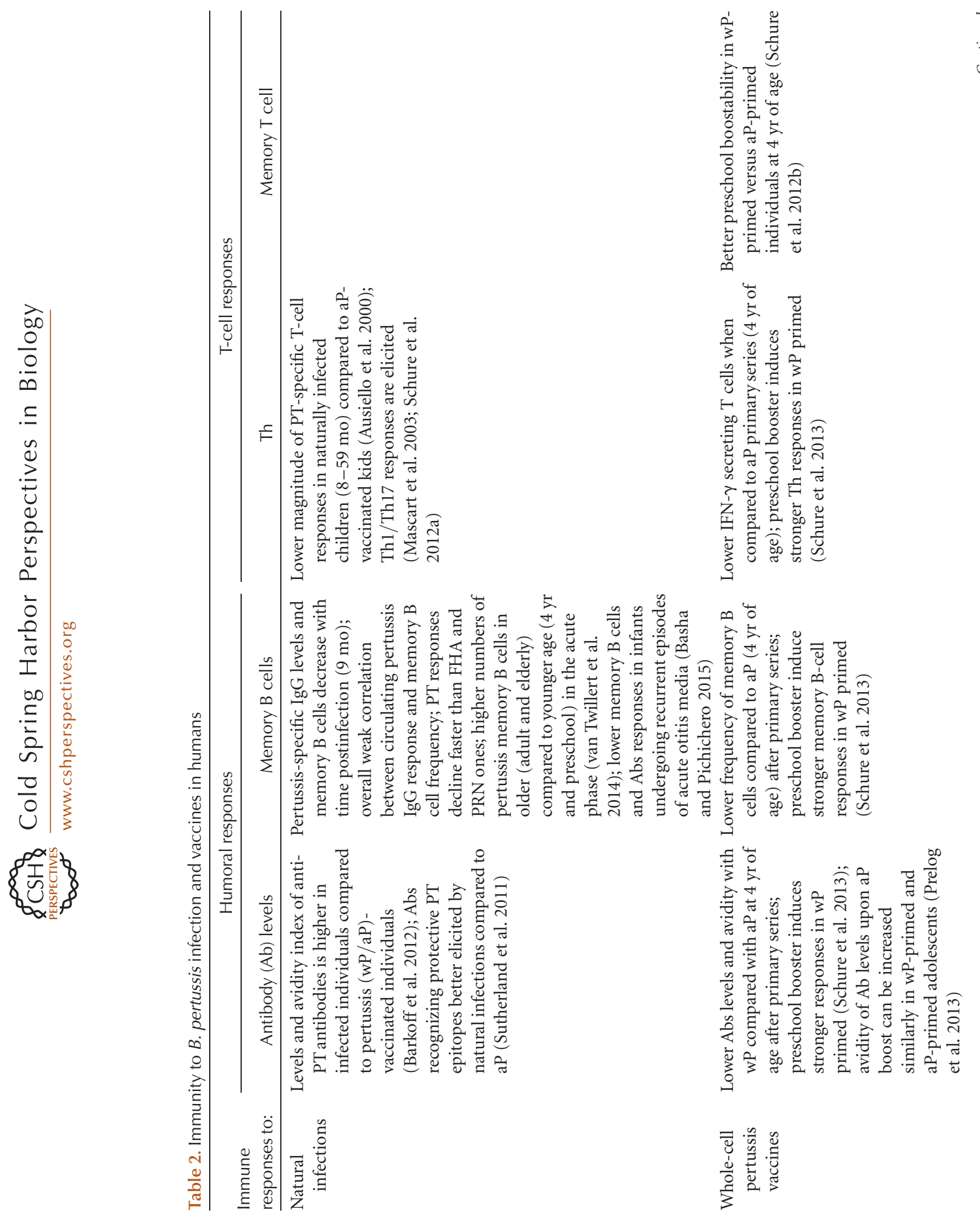
N. Burdin et al.

close to those induced by wP and natural infection, even if some studies support stronger booster effects in wP-primed individuals (Schure et al. 2013). The rapid decay of Ab responses seems thus to be related to specific attributes of Bordetella antigens rather than to the use of a subunit vaccine and could be partly explained by an intrinsic poor priming property of B. pertussis-specific B cells on antigen/pathogen encounter (van Twillert et al. 2015). In addition, like many pathogens causing persistent infections, B. pertussis has developed several mechanisms to subvert host immunity, such as defects in memory $\mathrm{T}$-cell homing (Nguyen et al. 2012), and induction of regulatory $\mathrm{T}$ cells (McGuirk et al. 2002; Ross et al. 2004, 2013; Coleman et al. 2012) that may negatively affect immune priming, including humoral responses.

Even less information is known about pertussis-specific T-cell responses elicited by vaccines. This has only been more recently investigated because of the resurgence of infections suggested to be partly associated with defects in T-cell immunity. The limited set of data indicates that aP vaccine induces Th2-skewed or mixed Th1/Th2 responses, whereas wP vaccines and natural infections skew T-cell responses toward a more Th1 profile (Mascart et al. 2003; Dirix et al. 2009; Higgs et al. 2012; Vermeulen et al. 2013; Edwards and Berbers 2014). Priming with $\mathrm{wP}$ (recalled with aP boosters) gives rise to a stronger Th1 response in adolescents than an aP priming (Smits et al. 2013). This has been recently confirmed by a study showing a transient increase in "bystander" IgE responses in infants and preschoolers having received only aP-containing vaccines versus those having been primed with wP (Holt et al. 2016). Very little was known of Th17 cells until rather recently, but two studies report that aP vaccines fail to elicit Th17 responses (Schure et al. 2012b, 2013). Additional findings in vitro on human cells may explain why aP, with its more restricted Ag composition and per the nature of the alum adjuvant used, is not as well equipped as wP and natural infection to trigger Th17 responses (Fedele et al. 2008, 2010; Dunne et al. 2015). Beyond this difference in T-helper polarization, few if any quantitative differences have been identified in humans between ${ }_{\mathrm{wP}}$ and $\mathrm{aP}$ immunizations: similar frequencies and equivalent persistence, if not more, of memory and helper $\mathrm{T}$ cells have been observed for $\mathrm{wP}$ and aP vaccines (Table 2 ). Similarly to humoral immunity, memory $\mathrm{T}$-cell responses can be sustained for years by aP boosters with little overt waning.

\section{ANIMAL MODELS}

To compensate for the limited inferences from clinical results, immune responses to pertussis vaccines have been more thoroughly deciphered in animal models. On top of a hypothetically weaker B-cell priming observed in humans, one mouse study provides possible mechanistic insights into the waning of humoral responses (Stenger et al. 2010). Three limitations in the long-term maintenance and function of pertussis memory $\mathrm{Ab}$ responses after aP were proposed: a more limited self-renewal capacity of memory B cells, a defect in the differentiation ratio between plasma cells and memory B cells from germinal center B cells, and an exhaustion of plasma cell in the bone marrow on accumulation of boosts. No other studies have, however, confirmed these hypotheses. Interestingly, it has also been described in mice that $B$. pertussis-specific memory B cells provide direct protection in the absence of circulating antibodies (Leef et al. 2000; Mahon et al. 2000), indicating their key role in protection provided they can support a functional booster response in due time before pertussis has time to develop.

Animal models have been very valuable to better understand the underlying mechanisms of the defect in T-cell skewing associated with aP vaccinations. In mice, it has been shown that aP vaccines differ from both $\mathrm{wP}$ vaccines and natural infection in terms of Th polarization. First, as observed in humans, aP induces a more balanced Th1/Th2 profile when compared to either wP or natural infection, which both direct a more Th1-skewed response (Mills et al. 1993, 1998; Brady et al. 1998; Sugai et al. 2005; Polewicz et al. 2013). Second, aP fails to 
N. Burdin et al.

elicit Th17-specific cells, whereas wP can better mimic natural infection by the induction of this particular subset (Higgs et al. 2012; Brummelman et al. 2015b; Dunne et al. 2015). More importantly, a recently developed baboon model nicely recapitulates pertussis disease and has become instrumental to investigating Bordetella immunity and to compare the different vaccines and infection (Warfel and Merkel 2014). This model is recognized as well suited to study pertussis vaccine performance for many reasons: it permits physiologically relevant intranasal challenges including in infant animals; the baboon immune system is close to the human one, including the same four IgG isotypes; and serial samplings including mucosal ones can be performed to track infection and precisely monitor protection. In baboons, aP vaccines protect adolescent primates as well as wP or natural infection against disease (no symptoms) but fail to prevent infection (colonization) and thus transmission (Warfel et al. 2014b). No major differences in $\mathrm{Ab}$ titers against the vaccine Ags were observed between $\mathrm{aP}$ and $\mathrm{wP}$ vaccines, indicating an important role of $\mathrm{T}$ cells in protection against infection. Accordingly, wP-vaccinated animals show a Th1/Th17 skewing similar (although milder) than the one induced by natural infection, whereas aP-vaccinated baboons show balanced Th1/Th2 responses, with no signs of Th17 immunity. In an infant challenge model, both maternal and neonatal vaccinations have been assessed (Warfel et al. 2014a). Although the study is limited by the number of animals used, maternal immunization with aP-induced vaccine-specific titers in neonates are sufficient to confer full protection against disease even if all were colonized. Similarly, aP vaccination of neonates (2 days old) induced significant antibody responses (that could be further boosted by an immunization at day 28), which fully protected baboons from disease even if they remained heavily colonized. These animal results suggest that the T-cell profile induced by aP vaccines is inefficient at conferring protection against colonization and hence transmission, and thus induction of a different $\mathrm{T}$-cell response may be crucial to more prolonged protection.

\section{HERD IMMUNITY}

The ability of wP to block transmission in humans remains a matter of debate: the Fine and Clarkson (1982) study failed to show prevention of transmission, whereas other studies have established strong signatures of herd immunity on mass vaccination (Preziosi and Halloran 2003; Wearing and Rohani 2009; Blackwood et al. 2013). One recent study in humans indicate that siblings are now the most common source of transmission to infants, although direct studies of colonization in humans are needed (Skoff et al. 2015). A recent public health investigation in Florida suggested that there is sustained transmission of $B$. pertussis in an aP-vaccinated cohort (Matthias et al. 2016). Not only, then, do aP-vaccinated children have waning immunity, but even those with immunity can contribute to ongoing circulation of disease. While it is difficult to measure asymptomatic carriage, Althouse and Scarpino have designed mathematical models based on the genetic analysis of $B$. pertussis isolates in the United States and United Kingdom, which suggests that some of the resurgence of $B$. pertussis infections can be explained by asymptomatic transmission (Althouse and Scarpino 2015). The possibility of a lower ability of aP to limit B. pertussis colonization is a key parameter to take into account when considering design of a more potent subunit pertussis vaccine.

\section{EVOLUTION OF B. pertussis}

Strain change as a mechanism has been proposed leading to resurgence (Mooi et al. 2014). For example, a recent genomic analysis of strains in an outbreak in the United Kingdom found that aP vaccine antigen-encoding genes evolved at a high rate than other surface proteinencoding genes, supporting the hypothesis that aP immunity may drive the evolution of B. pertussis (Sealey et al. 2015, 2016). Reassuringly, whereas pertactin-deficient strains are increasing in the United States, vaccine effectiveness was maintained in a setting of high $(>90 \%)$ pertactin-deficient circulating strains (Breakwell et al. 2016). Austrian investigators 
have identified more severe disease in infants infected with a polymorphism of the pertussis toxin operon, ptxP3, which results in increased toxin production. In a mouse model, Australian strains carrying the ptxP3 promoter colonized more efficiently than older strains (Safarchi et al. 2016). Other vaccine components may be more critical in preventing disease and additional studies examining the immune response to filamentous hemagglutinin or fimbrial antigens need to be conducted. In addition, strains with the ptxP3 promoter are more common in countries using aP than countries using wP, which provides another reason why pertussis has increased more in the former (He 2016).

\section{WHAT NEEDS TO BE DONE TO BETTER UNDERSTAND CURRENT SHORTCOMINGS OF THE AP LONG-TERM IMMUNITY?}

To have sustainable humoral responses with fewer boosters, a much more in-depth analysis of the induction, maintenance, and function of the plasma cell and memory B-cell pools is absolutely required to better understand what immune events limit the mobilization and amplification of memory arms. Similarly, more baboon and mouse studies are needed to confirm and better comprehend the differential Th skewing triggered by aP compared to natural infections or wP immunizations. Identifying the pathways and biomarkers that underpin those differences will be critical for the development of improved aP primary series vaccines. Those studies should exploit all the most recent technologies of system biology (transcriptomics, metabolomics, proteomics ...) for an in-depth differential characterization of the features of both vaccine types. First attempts to tackle this biomarker quest using Omics approaches have been initiated and some immune signatures preceding the generation of Th1 and Th17 cells and IgA in the lungs after natural infections were shown in mice ( $\mathrm{Ra}$ even et al. 2014). Similar studies should be performed in humans either primed with aP or wP vaccines, aiming to profile the different immune signatures imprinted during primary series, to confirm animal results and hopefully to corroborate preclinically identified biomarkers of aP defects.

It is of upmost importance to determine the magnitude and the nature (Th skewing) of sustained functional humoral and cellular memories that are required to support protection; this will establish the main immunologic criteria against which new aP vaccines can be selected. In addition, we do not know how $\mathrm{T}$ follicular helper cells ( $\mathrm{Tfh}$ ) are regulated during pertussis infections or immunizations, although these cells are known to be instrumental in orchestrating humoral memory immunity (Hale and Ahmed 2015).

\section{WHAT ARE THE OPTIONS TO IMPROVE CURRENT AP VACCINES?}

We must stress that aP vaccines remain very potent and safe vaccines that generally protect worldwide populations against $B$. pertussis disease. The short to mid-term protection is equal to that induced by wP pertussis. Recent resurgences and outbreaks have raised questions about the ability of aP priming to optimally support longer term protection, leading to the characterization of a different immune profile between $\mathrm{aP}$ and ${ }_{\mathrm{wP}}$ vaccines. However, this is definitely not the only causative factor to consider, as resurgences have also occurred in countries still using wP vaccines (Tan et al. 2015). Even if the underlying immune mechanisms of the long-term aP "weaknesses" are not yet fully elucidated, more Th2 skewed immune responses, some defects in memory $\mathrm{T}$ - and B-cell functions, and clinical and animal data jointly show that aP vaccine priming appears to be less optimal than after wP vaccines and natural infections. This is especially true for their ability to sustain long-term protection and fully efficient boostability (Bolotin et al. 2015).

Considering the good ability of aP to boost existing responses even if, for a short period of time, a less disruptive option could be to test new vaccine schedules in infants/adolescent to try to prevent waning of immunity (Sharma and Pichichero 2012). Priming with aP in infants is not efficient, but after the age of 5 (once immune maturity is fully reached) boosting is 
N. Burdin et al.

quite optimal (van Twillert et al. 2014) and more boosters could possibly fix the current situation (Gabutti et al. 2015). Change in infant vaccination however is not an easy task regulatory wise, and this option is probably not the most appropriate to make significant immune improvements. Vaccination of individuals having contact with newborns, often referred to as the "cocooning" strategy, and during pregnancy using current aP vaccines also are alternative options that when combined could have an impact to reduce resurgences and outbreaks (Plotkin 2014b).

The most reliable although more long-term option is to develop an improved aP vaccine to address its current shortcomings, using novel adjuvants or additional antigens, for long-term protection and prevention of colonization. This is the focus of many current efforts conducted by the public and private pertussis communities, as summarized in Brummelman et al. (2015b), Meade et al. (2014), and Plotkin (2014a) and shown in Figure 2 and noted in Table 3.

\section{CONCLUSIONS}

The phenomena of waning immunity after boosting on an aP background, inability to eliminate colonization, and evolution of $B$. pertussis require the improvement of aP vaccines. It should be added that a return to whole-cell vaccines will not be acceptable to the public and other solutions must be found. The improvement of aP is essentially an immunologic problem. In a nutshell, the two principal issues are to prolong B-cell effector memory so that antibody, particularly against PT, persists for a longer period of time, and to generate a Th1/Th17 T-cell environment early in life so that carriage of Bordetella is prevented. Both goals will require reformulation of pertussis vaccine constituents, both antigens and adjuvants. The most obvious strategies are to use genetically rather than chemically inactivated PT (Seubert et al. 2014); to use adjuvants that better stimulate innate immunity and memory; and/or to add new $B$. pertussis virulence factors to the vac-

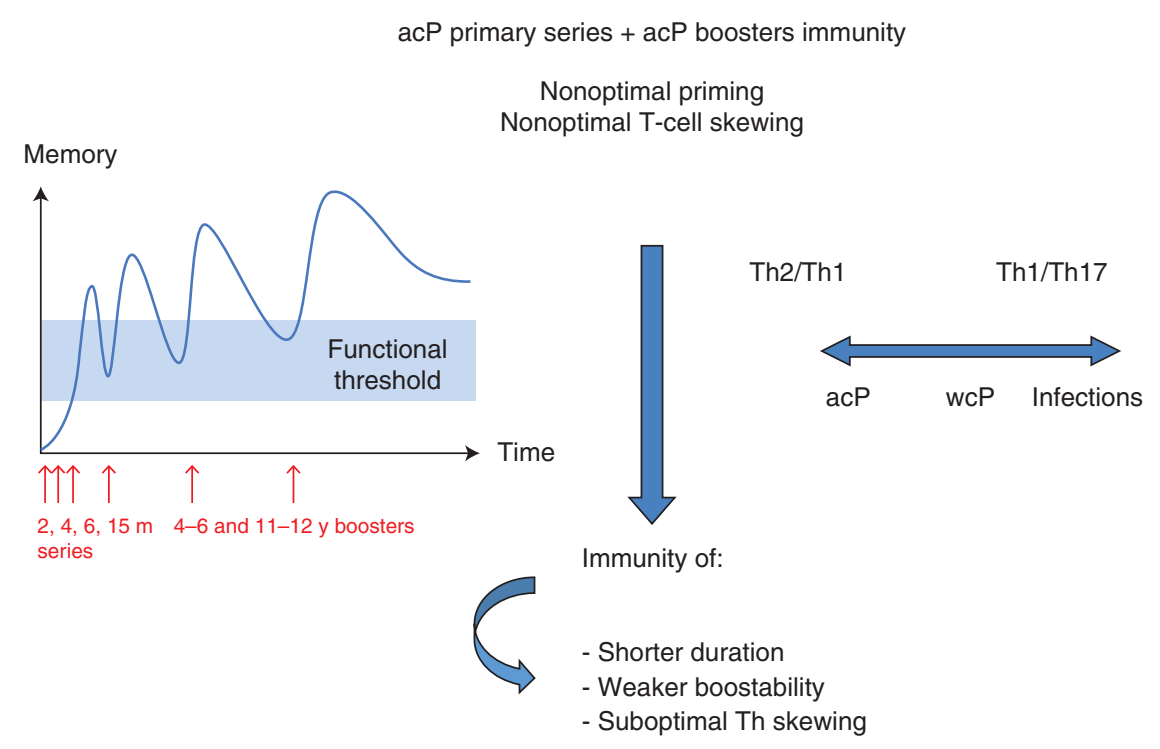

Figure 2. New aP vaccine should be aimed to increase priming and boostability of current subunit vaccine through the addition of adjuvants that will program a more Th1/Th17 immune profile and possibly the addition of more subunit Ags inducing bactericidal activity to limit or prevent colonization. Another option, not mutually exclusive, is to deliver the vaccine and/or induce a stronger immune response to a more physiologically relevant compartment for the disease (i.e., the lung) to trigger more potent mucosal responses with hopefully a better duration as well through a better homing of memory cells in the lung mucosa. Several Ags, adjuvants, and/or routes of immunizations harboring the above properties have already been reported in the literature. 
Table 3. Possible improvements of acellular pertussis vaccines

\begin{tabular}{lc}
\hline Options (not mutually exclusive) & Examples already reported \\
\hline $\begin{array}{l}\text { Enhances immune priming and favors a Th1/ } \\
\text { Th17 skewing with adjuvants }\end{array}$ & CpG (Sugai et al. 2005; Garlapati et al. 2011; Asokanathan \\
& et al. 2013; Polewicz et al. 2013; Ross et al. 2013) \\
& TLR4 agonist (Brummelman et al. 2015a, 2016) \\
& cdiGMP (Elahi et al. 2014) \\
& TLR-2 targeting lipoprotein (Dunne et al. 2015) \\
Decrease colonization to reduce transmission & Adenylate cyclase (Cheung et al. 2006; Sebo et al. 2014) \\
using Ags that induce bacterial killing & OMV (Roberts et al. 2008; Asensio et al. 2011) \\
Increase lung memory immunity & By intranasal route (Fedele et al. 2011; Skerry and Mahon \\
& 2011; Feunou et al. 2014; Jahnmatz et al. 2014a; \\
& Thorstensson et al. 2014) \\
& By intradermal route using patch (Halperin et al. 2002), DBV \\
& Technologies/BioNet-Asia/University of Geneva (Gavillet \\
& et al. 2015) \\
\hline
\end{tabular}

cine (Allen and Mills 2014; Rumbo and Hozbor 2014). Live pertussis vaccines are now under investigation, with possible advantages in conferring immunity as they mimic natural infection (Locht and Mielcarek 2014). Regulatory approval poses significant barriers to licensure of new vaccines, as traditional efficacy trials cannot be performed, and the appropriate antibody response to serve as a correlate of protection is disputed (Clark et al. 2012).

\section{ACKNOWLEDGMENTS}

The authors thank David R. Johnson, MD, $\mathrm{MPH}$ and Denis Macina, MPH (both from Sanofi Pasteur) for their careful review of the manuscript.

\section{REFERENCES}

Acosta AM, DeBolt C, Tasslimi A, Lewis M, Stewart LK, Misegades LK, Messonnier NE, Clark TA, Martin SW, Patel M. 2015. Tdap vaccine effectiveness in adolescents during the 2012 Washington State pertussis epidemic. Pediatrics 135: 981-989.

Allen AC, Mills KH. 2014. Improved pertussis vaccines based on adjuvants that induce cell-mediated immunity. Expert Rev Vaccines 13: 1253-1264.

Althouse BM, Scarpino SV. 2015. Asymptomatic transmission and the resurgence of Bordetella pertussis. BMC Med 13: 146 .

Asensio CJ, Gaillard ME, Moreno G, Bottero D, Zurita E, Rumbo M, van der Ley P, van der Ark A, Hozbor D. 2011. Outer membrane vesicles obtained from Bordetella per- tussis Tohama expressing the lipid A deacylase PagL as a novel acellular vaccine candidate. Vaccine 29: 1649-1656.

Asokanathan C, Corbel M, Xing D. 2013. A CpG-containing oligodeoxynucleotide adjuvant for acellular pertussis vaccine improves the protective response against Bordetella pertussis. Hum Vaccin Immunother 9: 325-331.

Ausiello CM, Urbani F, la Sala A, Lande R, Cassone A. 1997. Vaccine- and antigen-dependent type 1 and type 2 cytokine induction after primary vaccination of infants with whole-cell or acellular pertussis vaccines. Infect Immun 65: $2168-2174$.

Ausiello CM, Lande R, Urbani F, Di Carlo B, Stefanelli P, Salmaso S, Mastrantonio P, Cassone A. 2000. Cell-mediated immunity and antibody responses to Bordetella pertussis antigens in children with a history of pertussis infection and in recipients of an acellular pertussis vaccine. J Infect Dis 181: 1989-1995.

Bancroft T, Dillon MB, da Silva Antunes R, Paul S, Peters B, Crotty S, Lindestam Arlehamn CS, Sette A. 2016. Th1 versus Th2 T cell polarization by whole-cell and acellular childhood pertussis vaccines persists upon re-immunization in adolescence and adulthood. Cell Immunol 304305: 35-43.

Baretto L, Guasparini R, Meekison W, Noya F, Young L, Mills E. 2007. Humoral immunity 5 years after booster immunization with an adolescent and adult formulation combined tetanus, diphtheria, and 5-component acellular pertussis vaccine. Vaccine 25: 8172-8179.

Barkoff AM, Grondahl-Yli-Hannuksela K, Vuononvirta J, Mertsola J, Kallonen T, He Q. 2012. Differences in avidity of IgG antibodies to pertussis toxin after acellular pertussis booster vaccination and natural infection. Vaccine 30: 6897-6902.

Basha S, Pichichero ME. 2015. Poor memory B cell generation contributes to non-protective responses to DTaP vaccine antigens in otitis-prone children. Clin Exp Immunol 182: 314-322.

Bisgard KM, Rhodes P, Connelly BL, Bi D, Hahn C, Patrick S, Glode MP, Ehresmann KR. 2005. Pertussis vaccine effectiveness among children 6 to 59 months of age in the United States, 1998-2001. Pediatrics 116: e285-e294. 
N. Burdin et al.

Blackwood JC, Cummings DA, Broutin H, Iamsirithaworn S, Rohani P. 2013. Deciphering the impacts of vaccination and immunity on pertussis epidemiology in Thailand. Proc Natl Acad Sci 110: 9595-9600.

Bolotin S, Harvill ET, Crowcroft NS. 2015. What to do about pertussis vaccines? Linking what we know about pertussis vaccine effectiveness, immunology and disease transmission to create a better vaccine. Pathog Dis 73: ftv057.

Brady MT, Mahon BP, Mills KH. 1998. Pertussis infection and vaccination induces Th1 cells. Immunol Today 19: 534.

Breakwell L, Kelso P, Finley C, Schoenfeld S, Goode B, Misegades LK, Martin SW, Acosta AM. 2016. Pertussis vaccine effectiveness in the setting of pertactin-deficient pertussis. Pediatrics 137.

Brummelman J, Helm K, Hamstra HJ, van der Ley P, Boog CJ, Han WG, van Els CA. 2015a. Modulation of the CD4 $4^{+}$ $\mathrm{T}$ cell response after acellular pertussis vaccination in the presence of TLR4 ligation. Vaccine 33: 1483-1491.

Brummelman J, Wilk MM, Han WG, van Els CA, Mills KH. 2015b. Roads to the development of improved pertussis vaccines paved by immunology. Pathog Dis 73: ftv067.

Brummelman J, Raeven RH, Helm K, Pennings JL, Metz B, van Eden W, van Els CA, Han WG. 2016. Transcriptome signature for dampened Th2 dominance in acellular pertussis vaccine-induced $\mathrm{CD} 4^{+} \mathrm{T}$ cell responses through TLR4 ligation. Sci Rep 6: 25064.

Carollo M, Pandolfi E, Tozzi AE, Buisman AM, Mascart F, Ausiello CM. 2014. Humoral and B-cell memory responses in children five years after pertussis acellular vaccine priming. Vaccine 32: 2093-2099.

Cherry JD. 2012. Why do pertussis vaccines fail? Pediatrics 129: $968-970$.

Cherry JD. 2014. Adult pertussis in the pre- and post-vaccine eras: Lifelong vaccine-induced immunity? Expert Rev Vaccines 13: 1073-1080.

Cheung GY, Xing D, Prior S, Corbel MJ, Parton R, Coote JG. 2006. Effect of different forms of adenylate cyclase toxin of Bordetella pertussis on protection afforded by an acellular pertussis vaccine in a murine model. Infect Immun 74: 6797-6805.

Clark TA, Messonnier NE, Hadler SC. 2012. Pertussis control: Time for something new? Trends Microbiol 20: $211-$ 213.

Coleman MM, Finlay CM, Moran B, Keane J, Dunne PJ, Mills KH. 2012. The immunoregulatory role of $\mathrm{CD}^{+}$ FoxP $3^{+} \mathrm{CD} 25^{-}$regulatory $\mathrm{T}$ cells in lungs of mice infected with Bordetella pertussis. FEMS Immunol Med Microbiol 64: 413-424.

Dalby T, Petersen JW, Harboe ZB, Krogfelt KA. 2010. Antibody responses to pertussis toxin display different kinetics after clinical Bordetella pertussis infection than after vaccination with an acellular pertussis vaccine. J Med Microbiol 59: 1029-1036.

Decker MD, Edwards KM, Steinhoff MC, Rennels MB, Pichichero ME, Englund JA, Anderson EL, Deloria MA, Reed GF. 1995. Comparison of 13 acellular pertussis vaccines: Adverse reactions. Pediatrics 96: 557-566.

de Rond L, Schure RM, Ozturk K, Berbers G, Sanders E, van Twillert I, Carollo M, Mascart F, Ausiello CM, van Els CA, et al. 2015. Identification of pertussis-specific effector memory T cells in preschool children. Clin Vaccine Immunol 22: 561-569.

Dirix V, Verscheure V, Goetghebuer T, Hainaut M, Debrie AS, Locht C, Mascart F. 2009. Cytokine and antibody profiles in 1-year-old children vaccinated with either acellular or whole-cell pertussis vaccine during infancy. Vaccine 27: 6042-6047.

Domenech de Celles M, Magpantay FM, King AA, Rohani P. 2016. The pertussis enigma: Reconciling epidemiology, immunology and evolution. Proc Biol Sci doi: 10.1098/ rspb.2015.2309.

Dunne A, Mielke LA, Allen AC, Sutton CE, Higgs R, Cunningham CC, Higgins SC, Mills KH. 2015. A novel TLR2 agonist from Bordetella pertussis is a potent adjuvant that promotes protective immunity with an acellular pertussis vaccine. Mucosal Immunol 8: 607-617.

Edwards KM, Berbers GA. 2014. Immune responses to pertussis vaccines and disease. J Infect Dis 1: S10-S15.

Edwards KM, Decker MD. 2013. Pertussis vaccines. In Vaccines, 6th ed. (ed. Plotkin SA, Orenstein W, Offit P), pp. 447-492. Elsevier, Amsterdam.

Edwards KM, Meade BD, Decker MD, Reed GF, Rennels MB, Steinhoff MC, Anderson EL, Englund JA, Pichichero ME, Deloria MA. 1995. Comparison of 13 acellular pertussis vaccines: Overview and serologic response. Pediatrics 96: 548-557.

Elahi S, Van Kessel J, Kiros TG, Strom S, Hayakawa Y, Hyodo M, Babiuk LA, Gerdts V. 2014. c-di-GMP enhances protective innate immunity in a murine model of pertussis. PLoS ONE 9: e109778.

Fedele G, Nasso M, Spensieri F, Palazzo R, Frasca L, Watanabe M, Ausiello CM. 2008. Lipopolysaccharides from Bordetella pertussis and Bordetella parapertussis differently modulate human dendritic cell functions resulting in divergent prevalence of Th17-polarized responses. $J$ Immunol 181: 208-216.

Fedele G, Spensieri F, Palazzo R, Nasso M, Cheung GY, Coote JG, Ausiello CM. 2010. Bordetella pertussis commits human dendritic cells to promote a Th1/Th17 response through the activity of adenylate cyclase toxin and MAPK-pathways. PLoS ONE 5: e8734.

Fedele G, Bianco M, Debrie AS, Locht C, Ausiello CM. 2011. Attenuated Bordetella pertussis vaccine candidate BPZE1 promotes human dendritic cell CCL21-induced migration and drives a Th1/Th17 response. J Immunol 186: 5388-5396.

Feunou PF, Kammoun H, Debrie AS, Locht C. 2014. Heterologous prime-boost immunization with live attenuated $B$. pertussis BPZE1 followed by acellular pertussis vaccine in mice. Vaccine 32: 4281-4288.

Fine PE, Clarkson JA. 1982. The recurrence of whooping cough: Possible implications for assessment of vaccine efficacy. Lancet 1: 666-669.

Fulton TR, Phadke VK, Orenstein WA, Hinman AR, Johnson WD, Omer SB. 2016. Protective effect of contemporary pertussis vaccines: A systematic review and metaanalysis. Clin Infect Dis 62: 1100-1110.

Gabutti G, Azzari C, Bonanni P, Prato R, Tozzi AE, Zanetti A, Zuccotti G. 2015. Pertussis. Hum Vaccin Immunother 11: $108-117$. 
Garlapati S, Eng NF, Kiros TG, Kindrachuk J, Mutwiri GK, Hancock RE, Halperin SA, Potter AA, Babiuk LA, Gerdts V. 2011. Immunization with PCEP microparticles containing pertussis toxoid, CpG ODN and a synthetic innate defense regulator peptide induces protective immunity against pertussis. Vaccine 29: 6540-6548.

Gavillet BM, Mondoulet L, Dhelft V, Eberhardt CS, Auderset F, Pham HT, Petre J, Lambert PH, Benhamou PH, Siegrist CA. 2015. Needle-free and adjuvant-free epicutaneous boosting of pertussis immunity: Preclinical proof of concept. Vaccine 33: 3450-3455.

Greco D, Salmaso S, Mastrantonio P, Giuliano M, Tozzi AE, Anemona A, Ciofi degli Atti ML, Giammanco A, Panei P, Blackwelder WC, et al. 1996. A controlled trial of two acellular vaccines and one whole-cell vaccine against pertussis. Progetto Pertosse Working Group. N Engl J Med 334: 341-348.

Grondahl-Yli-Hannuksela K, Kauko L, Van Der Meeren O, Mertsola J, He Q. 2016. Pertussis specific cell-mediated immune responses ten years after acellular pertussis booster vaccination in young adults. Vaccine 34: 341349.

Gustafsson L, Hallander HO, Olin P, Reizenstein E, Storsaeter J. 1996. A controlled trial of a two-component acellular, a five-component acellular, and a whole-cell pertussis vaccine. N Engl J Med 334: 349-355.

Hale JS, Ahmed R. 2015. Memory T follicular helper CD4 T cells. Front Immunol 6: 16.

Halperin BA, Halperin SA, McGrath P, Smith B, Houston T. 2002. Use of lidocaine-prilocaine patch to decrease intramuscular injection pain does not adversely affect the antibody response to diphtheria-tetanus-acellular pertussis-inactivated poliovirus-haemophilus influenzae type $\mathrm{b}$ conjugate and hepatitis $\mathrm{B}$ vaccines in infants from birth to six months of age. Pediatr Infect Dis J 21: 399-405.

Halperin SA, Scheifele D, De Serres G, Noya F, Meekison W, Zickler P, Larrivée L, Langley JM, McNeil SA, Dobson S, et al. 2012. Immune responses in adults to revaccination with a tetanus toxoid, reduced diphtheria toxoid, and acellular pertussis vaccine 10 years after a previous dose. Vaccine 30: 974-982.

He Q. 2016. Evolution of Bordetella pertussis. Pediatr Infect Dis J 35: 915-917.

Hendrikx LH, de Rond LG, Ozturk K, Veenhoven RH, Sanders EA, Berbers GA, Buisman AM. 2011a. Impact of infant and preschool pertussis vaccinations on memory B-cell responses in children at 4 years of age. Vaccine 29: 5725-5730.

Hendrikx LH, Ozturk K, de Rond LG, Veenhoven RH, Sanders EA, Berbers GA, Buisman AM. 2011b. Identifying long-term memory B-cells in vaccinated children despite waning antibody levels specific for Bordetella pertussis proteins. Vaccine 29: 1431-1437.

Hendrikx LH, Schure RM, Ozturk K, de Rond LG, de Greeff SC, Sanders EA, Berbers GA, Buisman AM. 2011c. Different IgG-subclass distributions after whole-cell and acellular pertussis infant primary vaccinations in healthy and pertussis infected children. Vaccine 29: 6874-6880.

Hewlett EL, Edwards KM. 2005. Pertussis-Not just for kids. N Engl J Med 352: 1215-1222.
Higgs R, Higgins SC, Ross PJ, Mills KH. 2012. Immunity to the respiratory pathogen Bordetella pertussis. Mucosal Immunol 5: 485-500.

Holt PG, Snelling T, White OJ, Sly PD, DeKlerk N, Carapetis J, Biggelaar AV, Wood N, McIntyre P, Gold M. 2016. Transiently increased IgE responses in infants and preschoolers receiving only acellular diphtheria-pertussistetanus (DTaP) vaccines compared to those initially receiving at least one dose of cellular vaccine (DTwP) Immunological curiosity or canary in the mine? Vaccine 34: 4257-4262.

Huygen K, Cabore RN, Maertens K, Van Damme P, Leuridan E. 2015. Humoral and cell mediated immune responses to a pertussis containing vaccine in pregnant and nonpregnant women. Vaccine 33: 4117-4123.

Jahnmatz M, Amu S, Ljungman M, Wehlin L, Chiodi F, Mielcarek N, Locht C, Thorstensson R. 2014a. B-cell responses after intranasal vaccination with the novel attenuated Bordetella pertussis vaccine strain BPZE1 in a randomized phase I clinical trial. Vaccine 32: 3350-3356.

Jahnmatz M, Ljungman M, Netterlid E, Jenmalm MC, Nilsson L, Thorstensson R. 2014b. Pertussis-specific memory B-cell and humoral IgG responses in adolescents after a fifth consecutive dose of acellular pertussis vaccine. Clin Vaccine Immunol 21: 1301-1308.

Jefferson T, Rudin M, DiPietrantonj C. 2003. Systematic review of the effects of pertussis vaccines in children. Vaccine 21: 2003-2014.

Kilgore PE, Salim AM, Zervos MJ, Schmitt HJ. 2016. Pertussis: Microbiology, disease, treatment, and prevention. Clin Microbiol Rev 29: 449-486.

Klein NP. 2014. Licensed pertussis vaccines in the United States. History and current state. Hum Vaccin Immunother 10: 2684-2690.

Klein NP, Bartlett J, Rowhani-Rahbar A, Fireman B, Baxter R. 2012. Waning protection after fifth dose of acellular pertussis vaccine in children. $N$ Engl J Med 367: 1012 1019.

Klein NP, Bartlett J, Fireman B, Rowhani-Rahbar A, Baxter R. 2013. Comparative effectiveness of acellular versus whole-cell pertussis vaccines in teenagers. Pediatrics 131: e1716-e1722.

Klein NP, Bartlett J, Fireman B, Baxter R. 2016. Waning Tdap effectiveness in adolescents. Pediatrics 137: e20153326.

Koepke R, Eickhoff JC, Ayele RA, Petit AB, Schauer SL, Hopfensperger DJ, Conway JH, Davis JP. 2014. Estimating the effectiveness of tetanus-diphtheria-acellular pertussis vaccine (Tdap) for preventing pertussis: Evidence of rapidly waning immunity and difference in effectiveness by Tdap brand. J Infect Dis 210: 942-953.

Lacombe K, Yam A, Simondon K, Pinchinat S, Simondon F. 2004. Risk factors for acellular and whole-cell pertussis vaccine failure in Senegalese children. Vaccine 23: $623-$ 628.

Leef M, Elkins KL, Barbic J, Shahin RD. 2000. Protective immunity to Bordetella pertussis requires both B cells and $\mathrm{CD}_{4}^{+} \mathrm{T}$ cells for key functions other than specific antibody production. J Exp Med 191: 1841-1852.

Liko J, Robison SG, Cieslak PR. 2013. Priming with wholecell versus acellular pertussis vaccine. $N$ Engl J Med 368: $581-582$. 
N. Burdin et al.

Liko J, Robison SG, Cieslak P. 2014. Pertussis vaccine performance in an epidemic year-Oregon, 2012. Clin Infect Dis 59: 261-263.

Locht C. 2016. Pertussis: Acellular, whole-cell, new vaccines, what to choose? Expert Rev Vaccines 15: 671-673.

Locht C, Mielcarek N. 2014. Live attenuated vaccines against pertussis. Expert Rev Vaccines 13: 1147-1158.

Lugauer S, Heininger U, Cherry JD, Stehr K. 2002. Longterm clinical effectiveness of an acellular pertussis component vaccine and a whole cell pertussis component vaccine. Eur J Pediatr 161: 142-146.

Mahon BP, Brady MT, Mills KH. 2000. Protection against Bordetella pertussis in mice in the absence of detectable circulating antibody: Implications for long-term immunity in children. J Infect Dis 181: 2087-2091.

Mascart F, Verscheure V, Malfroot A, Hainaut M, Pierard D, Temerman S, Peltier A, Debrie AS, Levy J, Del Giudice G, et al. 2003. Bordetella pertussis infection in 2-month-old infants promotes type $1 \mathrm{~T}$ cell responses. J Immunol 170: 1504-1509.

Matthias J, Pritchard PS, Martin SW, Dusek C, Cathey E, D’Alessio R, Kirsch M. 2016. Sustained transmission of pertussis in vaccinated, 1-5-year-old children in a preschool, Florida, USA. Emerg Infect Dis 22: 242-246.

McGirr A, Fisman DN. 2015. Duration of pertussis immunity after DTaP immunization: A meta-analysis. Pediatrics 135: $331-343$.

McGuirk P, McCann C, Mills KH. 2002. Pathogen-specific T regulatory 1 cells induced in the respiratory tract by a bacterial molecule that stimulates interleukin 10 production by dendritic cells: A novel strategy for evasion of protective Thelper type 1 responses by Bordetella pertussis. J Exp Med 195: 221-231.

Meade BD, Plotkin SA, Locht C. 2014. Possible options for new pertussis vaccines. J Infect Dis 209: S24-S27.

Mills KH, Barnard A, Watkins J, Redhead K. 1993. Cellmediated immunity to Bordetella pertussis: Role of Th1 cells in bacterial clearance in a murine respiratory infection model. Infect Immun 61: 399-410.

Mills KH, Ryan M, Ryan E, Mahon BP. 1998. A murine model in which protection correlates with pertussis vaccine efficacy in children reveals complementary roles for humoral and cell-mediated immunity in protection against Bordetella pertussis. Infect Immun 66: $594-602$.

Misegades LK, Winter K, Harriman K, Talarico J, Messonnier NE, Clark TA, Martin SW. 2012. Association of childhood pertussis with receipt of 5 doses of pertussis vaccine by time since last vaccine dose, California, 2010. JAMA 308: $2126-2132$.

Mooi FR, Van Der Maas NA, De Melker HE. 2014. Pertussis resurgence: Waning immunity and pathogen adaptation-Two sides of the same coin. Epidemiol Infect 142: 685-694.

Nguyen TM, Ravindra D, Kwong B, Waheed S, Ferguson R, Tarlton N, Wu V, Sequeira CS, Bremer M, Abramson T. 2012. Differential expression of $\alpha 4$ integrins on effector memory $\mathrm{T}$ helper cells during Bordetella infections. Delayed responses in Bordetella pertussis. PLoS ONE 7: e52903.
Olin P. 1997 Commentary: The best acellular pertussis vaccines are multicomponent. Pediatr Infectious Dis J 16: 517-519

Palazzo R, Carollo M, Bianco M, Fedele G, Schiavoni I, Pandolfi E, Villani A, Tozzi AE, Mascart F, Ausiello CM. 2016. Persistence of T-cell immune response induced by two acellular pertussis vaccines in children five years after primary vaccination. New Microbiol 39: 35-47.

Pichichero ME, Deloria MA, Rennels MB, Anderson EL, Edwards KM, Decker MD, Englund JA, Steinhoff MC, Deforest A, Meade BD. 1997. A safety and immunogenicity comparison of 12 acellular pertussis vaccines and one whole-cell pertussis vaccine given as a fourth dose in 15- to 20-month-old children. Pediatrics 100: $772-788$.

Pichichero ME, Rennels MB, Edwards KM, Blatter MM, Marshall GS, Bologa M, Wang E, Mills E. 2005. Combined tetanus, diphtheria, and 5-component pertussis vaccine for use in adolescents and adults. JAMA 293: 3003-3011.

Pichichero ME, Blatter MM, Kennedy WA, Hedrick J, Descamps D, Friedland LR. 2006. Acellular pertussis vaccine booster combined with diphtheria and tetanus toxoids for adolescents. Pediatrics 117: 1084-1093.

Plotkin SA. 1997. The effectiveness of whole-cell pertussis vaccines. Dev Biol Stand 89: 171-174.

Plotkin SA. 2013. Complex correlates of protection after vaccination. Clin Infect Dis 56: 1458-1465.

Plotkin SA. 2014a. The pertussis problem. Clin Infect Dis 58: 830-833.

Plotkin SA. 2014b. Pertussis: Pertussis control strategies and the options for improving current vaccines. Expert Rev Vaccines 13: 1071-1072.

Plotkin SA, Cadoz M. 1997. The acellular pertussis vaccine trials: An interpretation. Pediatr Infect Dis J 16: 508517.

Polewicz M, Gracia A, Garlapati S, van Kessel J, Strom S, Halperin SA, Hancock RE, Potter AA, Babiuk LA, Gerdts V. 2013. Novel vaccine formulations against pertussis offer earlier onset of immunity and provide protection in the presence of maternal antibodies. Vaccine 31: 3148 3155 .

Prelog M, Almanzar G, Rieber N, Ottensmeier B, Zlamy M, Liese J. 2013. Differences of IgG antibody avidity after an acellular pertussis (aP) booster in adolescents after a whole cell $(\mathrm{wP})$ or aP primary vaccination. Vaccine 31 : 387-393.

Preziosi MP, Halloran ME. 2003. Effects of pertussis vaccination on transmission: Vaccine efficacy for infectiousness. Vaccine 21: 1853-1861.

Quinn HE, Snelling TL, Macartney KK, McIntyre PB.2014. Duration of protection after first dose of acellular pertussis vaccine in infants. Pediatrics 133: e513-e519.

Raeven RH, Brummelman J, Pennings JL, Nijst OE, Kuipers B, Blok LE, Helm K, van Riet E, Jiskoot W, van Els CA, et al. 2014. Molecular signatures of the evolving immune response in mice following a Bordetella pertussis infection. PLoS ONE 9: e104548.

Rieber N, Graf A, Hartl D, Urschel S, Belohradsky BH, Liese J. 2011. Acellular pertussis booster in adolescents induces 
Th1 and memory $\mathrm{CD}^{+} \mathrm{T}$ cell immune response. PLoS ONE 6: e17271.

Roberts R, Moreno G, Bottero D, Gaillard ME, Fingermann M, Graieb A, Rumbo M, Hozbor D. 2008. Outer membrane vesicles as acellular vaccine against pertussis. $\mathrm{Vac}$ cine 26: 4639-4646.

Ross PJ, Lavelle EC, Mills KH, Boyd AP. 2004. Adenylate cyclase toxin from Bordetella pertussis synergizes with lipopolysaccharide to promote innate interleukin-10 production and enhances the induction of Th2 and regulatory T cells. Infect Immun 72: 1568-1579.

Ross PJ, Sutton CE, Higgins S, Allen AC, Walsh K, Misiak A, Lavelle EC, McLoughlin RM, Mills KH. 2013. Relative contribution of Th1 and Th17 cells in adaptive immunity to Bordetella pertussis: Towards the rational design of an improved acellular pertussis vaccine. PLoS Pathog 9: e1003264.

Rumbo M, Hozbor D. 2014. Development of improved pertussis vaccine. Hum Vaccin Immunother 10: 2450 2453.

Ryan M, Murphy G, Ryan E, Nilsson L, Shackley F, Gothefors L, Oymar K, Miller E, Storsaeter J, Mills KH. 1998. Distinct T-cell subtypes induced with whole-cell and acellular pertussis vaccines in children. Immunology 93: $1-10$.

Safarchi A, Octavia S, Luu LD, Tay CY, Sintchenko V, Wood N, Marshall H, McIntyre P, Lan R. 2016. Better colonisation of newly emerged Bordetella pertussis in the co-infection mouse model study. Vaccine 34: 3967-3971.

Salmaso S, Mastrantonio P, Tozzi AE, Stefanelli P, Anemona A, Ciofi degli Atti ML, Giammanco A. 2001. Sustained efficacy during the first 6 years of life of 3-component acellular pertussis vaccines administered in infancy: The Italian experience. Pediatrics 108: E81.

Schure RM, de Rond L, Ozturk K, Hendrikx L, Sanders E, Berbers G, Buisman AM. 2012a. Pertussis circulation has increased T-cell immunity during childhood more than a second acellular booster vaccination in Dutch children 9 years of age. PLoS ONE 7: e41928.

Schure RM, Hendrikx LH, de Rond LG, Ozturk K, Sanders EA, Berbers GA, Buisman AM. 2012b. T-cell responses before and after the fifth consecutive acellular pertussis vaccination in 4-year-old Dutch children. Clin Vaccine Immunol 19: 1879-1886.

Schure RM, Hendrikx LH, de Rond LG, Oxturk K, Sanders EA, Berbers GA, Buisman AM. 2013. Differential T- and $\mathrm{B}$-cell responses to pertussis in acellular vaccine-primed versus whole-cell vaccine-primed children 2 years after preschool acellular booster vaccination. Clin Vaccine Immunol 20: 1388-1395.

Sealey KL, Harris SR, Fry NK, Hurst LD, Gorringe AR, Parkhill J, Preston A. 2015. Genomic analysis of isolates from the United Kingdom 2012 pertussis outbreak reveals that vaccine antigen genes are unusually fast evolving. J Infect Dis 212: 294-301.

Sealey KL, Belcher T, Preston A. 2016. Bordetella pertussis epidemiology and evolution in the light of pertussis resurgence. Infect Genet Evol 40: 136-143.

Sebo P, Osicka R, Masin J. 2014. Adenylate cyclase toxinhemolysin relevance for pertussis vaccines. Expert Rev Vaccines 13: 1215-1227.
Seubert A, D’Oro U, Scarselli M, Pizza M. 2014. Genetically detoxified pertussis toxin (PT-9K/129G): Implications for immunization and vaccines. Expert Rev Vaccines 13: 1191-1204.

Sharma SK, Pichichero ME. 2012. Functional deficits of pertussis-specific $\mathrm{CD} 4^{+} \mathrm{T}$ cells in infants compared to adults following DTaP vaccination. Clin Exp Immunol 169: $281-291$.

Sheridan SL, Ware RS, Grimwood K, Lambert SB. 2012. Number and order of whole cell pertussis vaccines in infancy and disease protection. JAMA 308: 454-456.

Sheridan SL, Frith K, Snelling TL, Grimwood K, McIntyre PB, Lambert SB. 2014. Waning vaccine immunity in teenagers primed with whole cell and acellular pertussis vaccine: Recent epidemiology. Expert Rev Vaccines 13: 1081 1106.

Sizaire V, Garrido-Estepa M, Masa-Calles J, Martinez de Aragon MV. 2014. Increase of pertussis incidence in 2010 to 2012 after 12 years of low circulation in Spain. Euro Surveill 19: 20875.

Skerry CM, Mahon BP. 2011. A live, attenuated Bordetella pertussis vaccine provides long-term protection against virulent challenge in a murine model. Clin Vaccine Immunol 18: 187-193.

Skoff TH, Martin SW. 2016. Impact of tetanus toxoid, reduced diphtheria toxoid, and acellular pertussis vaccinations on reported pertussis cases among those 11 to 18 years of age in an era of waning pertussis immunity: A follow-up analysis. JAMA Pediatr 170: 453-458.

Skoff TH, Kenyon C, Cocoros N, Liko J, Miller L, Kudish K, Baumbach J, Zansky S, Faulkner A, Martin SW. 2015. Sources of infant pertussis infection in the United States. Pediatrics 136: 635-641.

Smits K, Pottier G, Smet J, Dirix V, Vermeulen F, De Schutter I, Carollo M, Locht C, Ausiello CM, Mascart F. 2013. Different $\mathrm{T}$ cell memory in preadolescents after wholecell or acellular pertussis vaccination. Vaccine 32: 111118.

Stenger RM, Smits M, Kuipers B, van Gaans-van den Brink J, Poelen M, Boog CJ, van Els CA. 2010. Impaired longterm maintenance and function of Bordetella pertussis specific B cell memory. Vaccine 28: 6637-6646.

Sugai T, Mori M, Nakazawa M, Ichino M, Naruto T, Kobayashi N, Kobayashi Y, Minami M, Yokota S. 2005. ACpGcontaining oligodeoxynucleotide as an efficient adjuvant counterbalancing the Th1/Th2 immune response in diphtheria-tetanus-pertussis vaccine. Vaccine 23: 54505456.

Sutherland JN, Chang C, Yoder SM, Rock MT, Maynard JA. 2011. Antibodies recognizing protective pertussis toxin epitopes are preferentially elicited by natural infection versus acellular immunization. Clin Vaccine Immunol 18: $954-962$.

Tan T, Dalby T, Forsyth K, Halperin SA, Heininger U, Hozbor D, Plotkin S, Ulloa-Gutierrez R, Wirsing von Konig CH. 2015. Pertussis across the globe: Recent epidemiologic trends from 2000 to 2013. Pediatr Infect Dis J 34: e222-e232.

Tartof SY, Lewis M, Kenyon C, White K, Osborn A, Liko J, Zell E, Martin S, Messonnier NE, Clark TA, et al. 2013. Waning immunity to pertussis following 5 doses of DTaP. Pediatrics 131: e1047-e1052. 
N. Burdin et al.

Thorstensson R, Trollfors B, Al-Tawil N, Jahnmatz M, Bergstrom J, Ljungman M, Torner A, Wehlin L, Van Broekhoven A, Bosman F, et al. 2014. A phase I clinical study of a live attenuated Bordetella pertussis vaccine-BPZE1; a single centre, double-blind, placebo-controlled, dose-escalating study of BPZE1 given intranasally to healthy adult male volunteers. PLoS ONE 9: e83449.

van Twillert I, van Gaans-van den Brink JA, Poelen MC, Helm K, Kuipers B, Schipper M, Boog CJ, Verheij TJ, Versteegh FG, van Els CA. 2014. Age related differences in dynamics of specific memory B cell populations after clinical pertussis infection. PLOS ONE 9: e85227.

van Twillert I, Han WG, van Els CA. 2015. Waning and aging of cellular immunity to Bordetella pertussis. Pathog Dis 73: ftv071.

Vermeulen F, Dirix V, Verscheure V, Damis E, Vermeylen D, Locht C, Mascart F. 2013. Persistence at one year of age of antigen-induced cellular immune responses in preterm infants vaccinated against whooping cough: Comparison of three different vaccines and effect of a booster dose. Vaccine 31: 1981-1986.

Versteegh FG, Schellekens JF, Nagelkerke AF, Roord JJ. 2002. Laboratory-confirmed reinfections with Bordetella pertussis. Acta Paediatr 91: 95-97.

Warfel JM, Merkel TJ. 2014. The baboon model of pertussis: Effective use and lessons for pertussis vaccines. Expert Rev Vaccines 13: 1241-1252.

Warfel JM, Papin JF, Wolf RF, Zimmerman LI, Merkel TJ. 2014a. Maternal and neonatal vaccination protects newborn baboons from pertussis infection. J Infect Dis 210: 604-610.

Warfel JM, Zimmerman LI, Merkel TJ. 2014b. Acellular pertussis vaccines protect against disease but fail to prevent infection and transmission in a nonhuman primate model. Proc Natl Acad Sci 111: 787-792.

Wearing HJ, Rohani P. 2009. Estimating the duration of pertussis immunity using epidemiological signatures. PLoS Pathog 5: e1000647.

Wendelboe AM, Van Rie A, Salmaso S, Englund JA. 2005. Duration of immunity against pertussis after natural infection or vaccination. Pediatr Infect Dis J 24: S58S61.

White OJ, Rowe J, Richmond P, Marshall H, McIntyre P, Wood N, Holt PG. 2010. Th2-polarisation of cellular immune memory to neonatal pertussis vaccination. Vaccine 28: $2648-2652$.

Winter K, Harriman K, Zipprich J, Schechter R, Talarico J, Watt J, Chavez G. 2012. California pertussis epidemic, 2010. J Pediatr 161: 1091-1096.

Wirsing von Konig CH, Postels-Multani S, Bock HL, Schmitt HJ. 1995. Pertussis in adults: Frequency of transmission after household exposure. Lancet 346: $1326-$ 1329.

Witt MA, Katz PH, Witt DJ. 2012. Unexpectedly limited durability of immunity following acellular pertussis vaccination in preadolescents in a North American outbreak. Clin Infect Dis 54: 1730-1735.

Witt MA, Arias L, Katz PH, Truong ET, Witt DJ. 2013. Reduced risk of pertussis among persons ever vaccinated with whole cell pertussis vaccine compared to recipients of acellular pertussis vaccines in a large US cohort. Clin Infect Dis 56: 1248-1254.

World Health Organization. 2015. Position paper-Pertussis vaccines. Weekly Epidemiology Record, Vol. 90, September, pp. $433-458$. 


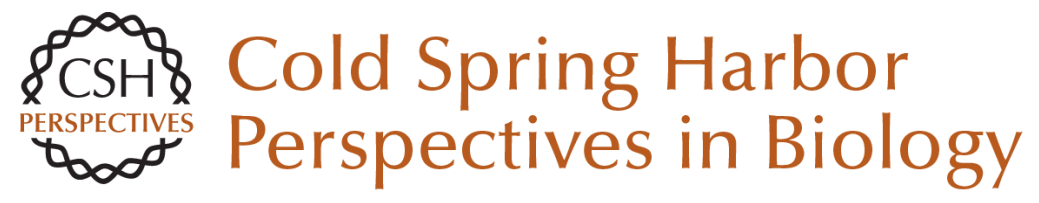

\title{
What Is Wrong with Pertussis Vaccine Immunity?: The Problem of Waning Effectiveness of Pertussis Vaccines
}

\author{
Nicolas Burdin, Lori Kestenbaum Handy and Stanley A. Plotkin \\ Cold Spring Harb Perspect Biol 2017; doi: 10.1101/cshperspect.a029454 originally published online \\ March 13, 2017
}

Subject Collection Immune Memory and Vaccines: Great Debates

Is There Natural Killer Cell Memory and Can It Be Harnessed by Vaccination?: Can Natural Killer and CD8 T Cells Switch Jobs?

Christine A. Biron and Marcus Altfeld

Is There Natural Killer Cell Memory and Can It Be Harnessed by Vaccination?: Vaccination Strategies Based on NK Cell and ILC Memory Megan A. Cooper, Todd A. Fehniger and Marco Colonna

Is It Possible to Develop Cancer Vaccines to Neoantigens, What Are the Major Challenges, and How Can These Be Overcome?: Neoantigens as Vaccine Targets for Cancer Haydn T. Kissick

Is It Possible to Develop Cancer Vaccines to Neoantigens, What Are the Major Challenges, and How Can These Be Overcome?: Neoantigens: Nothing New in Spite of the Name

Olivera J. Finn and Hans-Georg Rammensee

Which Dengue Vaccine Approach Is the Most Promising, and Should We Be Concerned about Enhanced Disease after Vaccination?: The Challenges of a Dengue Vaccine

Gavin Screaton and Juthathip Mongkolsapaya
Is There Natural Killer Cell Memory and Can It Be Harnessed by Vaccination?: NK Cell Memory and Immunization Strategies against Infectious Diseases and Cancer Joseph C. Sun and Lewis L. Lanier

Is There Natural Killer Cell Memory and Can It Be Harnessed by Vaccination?: Natural Killer Cells in Vaccination

Harold R. Neely, Irina B. Mazo, Carmen Gerlach, et al.

Is It Possible to Develop Cancer Vaccines to Neoantigens, What Are the Major Challenges, and How Can These Be Overcome?: Targeting the Right Antigens in the Right Patients Stephen P. Schoenberger

Which Dengue Vaccine Approach Is the Most Promising, and Should We Be Concerned about Enhanced Disease after Vaccination?: There Is Only One True Winner Scott B. Halstead

Which Dengue Vaccine Approach Is the Most Promising, and Should We Be Concerned about Enhanced Disease after Vaccination?: Questions Raised by the Development and Implementation of Dengue Vaccines: Example of the Sanofi Pasteur Tetravalent Dengue Vaccine Bruno Guy

For additional articles in this collection, see http://cshperspectives.cshlp.org/cgi/collection/

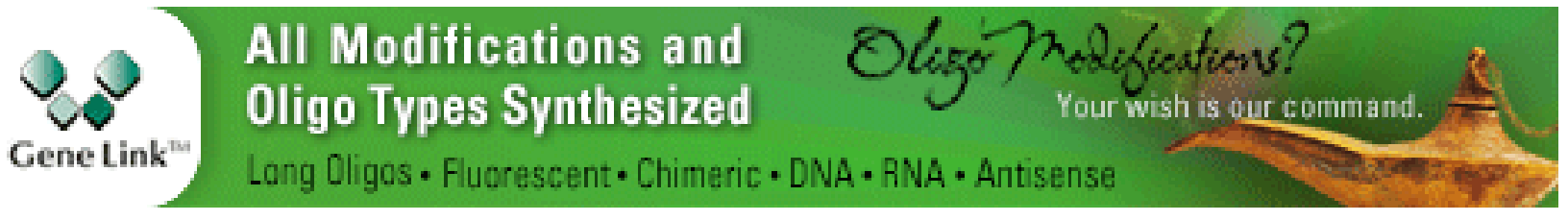


Which Dengue Vaccine Approach Is the Most Promising, and Should We Be Concerned about Enhanced Disease after Vaccination?: The Path to a Dengue Vaccine: Learning from Human Natural Dengue Infection Studies and Vaccine Trials Aravinda M. de Silva and Eva Harris

Is It Possible to Develop a "Universal" Influenza Virus Vaccine?: Potential for a Universal Influenza Vaccine

James E. Crowe, Jr.

Is It Possible to Develop a "Universal" Influenza Virus Vaccine?: Outflanking Antibody Immunodominance on the Road to Universal Influenza Vaccination

Davide Angeletti and Jonathan W. Yewdell
Which Dengue Vaccine Approach Is the Most Promising, and Should We Be Concerned about Enhanced Disease after Vaccination?: The Risks of Incomplete Immunity to Dengue Virus Revealed by Vaccination

Stephen S. Whitehead and Kanta Subbarao

Is It Possible to Develop a "Universal" Influenza Virus Vaccine?: Immunogenetic Considerations Underlying B-Cell Biology in the Development of a Pan-Subtype Influenza A Vaccine Targeting the Hemagglutinin Stem

Sarah F. Andrews, Barney S. Graham, John R. Mascola, et al.

Is It Possible to Develop a "Universal" Influenza Virus Vaccine?: Potential Target Antigens and Critical Aspects for a Universal Influenza Vaccine Florian Krammer, Adolfo García-Sastre and Peter Palese

For additional articles in this collection, see http://cshperspectives.cshlp.org/cgi/collection/

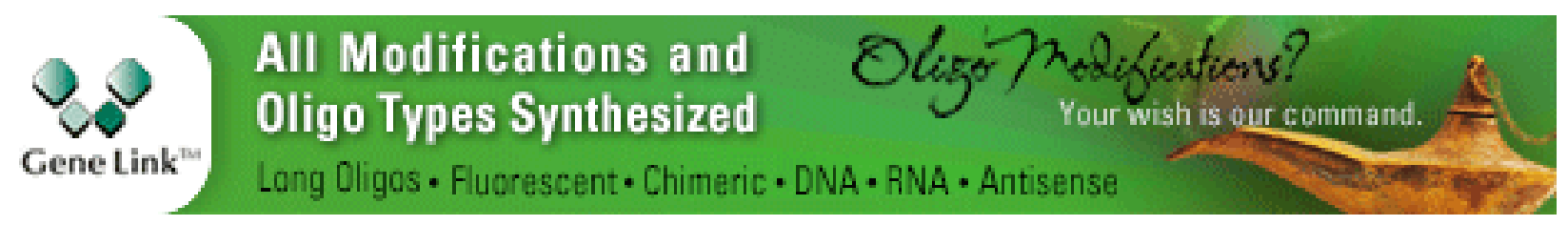

Copyright @ 2017 Cold Spring Harbor Laboratory Press; all rights reserved 